\title{
United Cities and Local Governments (UCLG) Policy Statement: 'Culture: Fourth Pillar of Sustainable Development'
}

\author{
UCLG Committee on Culture
}

\begin{abstract}
On November 17, 2010, the Executive Bureau of United Cities and Local Governments approved a policy statement on Culture as the Fourth Pillar of Sustainable Development, in the framework of the 'World Summit of Local and Regional Leaders', the third World Congress of UCLG, held in the City of Mexico.
\end{abstract}

This article reproduces the text of the policy statement. The introductory text has been slightly edited for this publication.

\section{The role of the United Cities and Local Governments and the UCLG Committee on Culture}

The long-standing commitment of local and regional authorities to the promotion of culture as a vital part of development and as an unavoidable prerequisite for a diverse and peaceful society has led the United Cities and Local Governments to mainstream culture in its current work and to promote the adoption by cities and regional authorities of the Agenda 21 for Culture. Building on UNESCO's Universal Declaration on Cultural Diversity (2001) and Convention on the Diversity of Cultural Expressions (2005), the Executive Bureau of United Cities and Local Governments agreed at its meeting in Chicago (April 2010) to mandate the UCLG Committee on Culture to develop a policy statement on 'Culture as the Fourth Pillar of Sustainable Development'. The first draft of the policy statement circulated to the members of the Executive Bureau and to the UCLG members active in the field of culture in June 2010. The final draft of the policy statement contained the comments received.

The content of this policy statement will translate to concrete actions to be developed closely with the regional sections and thematic committees. Among the actions the policy statement is envisaged to develop are: lobbying and advocacy before the international community; the exchange of practices, experiences, and mutual learning; and capacity building projects.

United Cities and Local Governments (UCLG) represents and advances the interests of cities, local governments, and municipal associations throughout the world on the international level. The Committee on Culture of UCLG is a unique platform, the only structure at a global level that gathers together cities, organizations, and networks that foster the relation between local cultural policies and sustainable development. It has 64 members and 40 observers. It is chaired by the City of Barcelona and vice-chaired by the Cities of Buenos Aires, Lille, Montreal,

This document was developed by the Committee on Culture of United Cities and Local Governments (UCLG). Secretariat: Barcelona, Spain. E-mail: agenda21cultura@bcn.cat

Culture and Local Governance / Culture et gouvernance locale, vol. 3, no. 1-2, 2011. ISSN 1911-7469

(C) Centre on Governance, University of Ottawa, 55 Laurier Avenue East, Ottawa, Ontario, Canada K1N 6N5 
and Stockholm. The mission of the Committee on Culture for 2011-2013 is "to promote culture as the fourth pillar of sustainable development through the international dissemination and the local implementation of Agenda 21 for culture."

\section{Background}

A vision of sustainable development with three dimensions was developed in the second half of the 1980s, namely: economic growth, social inclusion and environmental balance. The report Our Common Future, also known as the Brundtland Report (1987), enshrined these three dimensions as the pattern to be used in local, national and global strategies for development. The Rio de Janeiro Earth Summit of 1992 consolidated these three pillars as the paradigm of sustainable development. It is generally felt, however, that these dimensions alone cannot possibly reflect the complexity of current society. Many voices, including UNESCO, the World Summit on Sustainable Development, and researchers, are calling for the inclusion of Culture in the sustainable development model, since culture ultimately shapes what we mean by development and determines how people act in the world.

This new approach addresses the relation between culture and sustainable development through dual means: firstly, the development of the cultural sector itself (i.e., heritage, creativity, cultural industries, crafts, cultural tourism); and secondly, ensuring that culture has its rightful place in all public policies, particularly those related to education, the economy, science, communication, environment, social cohesion, and international cooperation.

The world is not only facing economic, social, or environmental challenges. Creativity, knowledge, diversity, and beauty are the unavoidable bases for dialogue for peace and progress as these values are intrinsically connected to human development and freedoms. While we have a duty to promote the continuity of indigenous local cultures, old traditions meet new creativity every day in cities around the world, contributing to the preservation of identity and diversity. Intercultural dialogue is one of humankind's greatest challenges and creativity is identified as an inexhaustible resource nourishing society and economy.

\section{Local governments safeguarding culture for future generations}

The fundamental purpose of governance is to work towards a healthy, safe, tolerant and creative society (rather than merely a financially prosperous one). This means that local governments must promote a model of development that 'meets the needs of the present without compromising the ability of future generations to meet their own needs', as well as ensuring the enjoyment of culture and its components by all, and protecting and enhancing the rights of citizens to freedom of expression and access to information and resources.

The world's cultural challenges are too important for them not to receive an equal amount of attention to that accorded to the original three dimensions of sustainable development (the economy, social equality, and environmental balance). This fourth pillar creates solid bridges with the other three dimensions of development and is compatible with each of them. 
UCLG POLICY STATEMENT Culture: Fourth Pillar of Sustainable Development

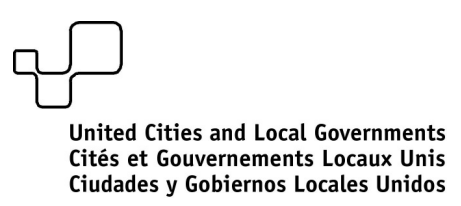

Mayors, Presidents, municipal leaders and practitioners, representing local and regional authorities as well as their associations worldwide, gathered in Mexico City on the occasion of the $3^{\text {rd }}$ World Congress of United Cities and Local Governments:

Recalling UNESCO's Universal Declaration on Cultural Diversity, UNESCO's Convention on the Diversity of Cultural Expressions, and Agenda 21 for Culture;

Recalling that the lack of consideration of the cultural dimension of development is hindering the possibility of achieving sustainable development, peace and wellbeing;

Recognizing that the trio of economic growth, social inclusion and environmental balance no longer reflect all the dimensions of our global societies;

Recognizing that the fundamental purpose of governance is to work towards a healthy, safe, tolerant and creative society, and that this requires the promotion by local governments of a model of development that 'meets the needs of the present without compromising the ability of future generations to meet their own needs', as well as ensuring the universal enjoyment of culture and its components, and protecting and enhancing the rights of citizens to freedom of expression and access to information and resources;

Affirming that culture in all its diversity is needed to respond to the current challenges of humankind;

Believing that governance at all levels (local, national and international) should include a strong cultural dimension;

The members of United Cities and Local Governments share the vision that culture is the fourth pillar of sustainable development.

United Cities and Local Governments calls on cities and local and regional governments around the world to:

- Integrate the dimension of culture into their development policies;

- Develop a solid cultural policy;

- Include a cultural dimension in all public policies;

- $\quad$ Promote the idea of culture as the fourth pillar internationally, in particular in international policy making. 


\section{United Cities and Local Governments calls on national governments to:}

- $\quad$ Bring a cultural perspective to national development plans as a whole;

- Establish concrete objectives and actions concerning culture in areas such as education, the economy, science, communication, environment, social cohesion and international cooperation;

- $\quad$ Promote the idea of culture as the fourth pillar internationally, in particular in international policy making.

United Cities and Local Governments calls on the United Nations, development agencies and the international community to:

- $\quad$ Explicitly integrate culture into programmes on sustainable development;

- Promote the international debate on the implications of the inclusion of culture as fourth pillar of development;

- $\quad$ Foster the inclusion of culture in international policy making.

For more information:

Committee on Culture

United Cities and Local Governments

www.cities-localgovernments.org

Agenda 21 for Culture

www.agenda21culture.net 